TITLE:

\title{
Preparation of collagen/gelatin sponge scaffold for sustained release of bFGF(Abstract_要旨 )
}

\author{
$\operatorname{AUTHOR(S):~}$ \\ Takemoto, Satoru
}

\section{CITATION:}

Takemoto, Satoru. Preparation of collagen/gelatin sponge scaffold for sustained release of bFGF. 京都大学, 2008, 博士(医学)

ISSUE DATE:

2008-03-24

URL:

http://hdl.handle.net/2433/135869

RIGHT: 


\begin{tabular}{|c|c|}
\hline 名 & 武 告 \\
\hline 学位 (専攻分野) & 士（医＼cjkstart学） \\
\hline 学 位 記 番 号 & 医 博 第 3249 号 \\
\hline 学位授与の日付 & 平 成 20 年 3 月 24 日 \\
\hline 学位授与の要件 & 学 位 規則第 4 条第 1 項該当 \\
\hline 研究科 · 専攻 & 医 学 研 究 科 外 科 系 専 攻 \\
\hline 学位論文題目 & $\begin{array}{l}\text { Preparation of collagen/gelatin sponge scaffold for sustained release of } \\
\text { bFGF }\end{array}$ \\
\hline
\end{tabular}

(bFGF の徐放が可能なコラーゲン/ゼラチンスポンジ作製)

論文調査委員教主授杏地良樹教授乾賢一 教授富田直秀

\section{論文内容 の 要旨}

コラーゲンスポンジは熱傷や外傷などの全層皮膚欠損創の治療に用いられている。移植後、スポンジ内に創床から線維芽 細胞と毛細血管が侵入する。コラーゲンスポンジは分解吸収され、線維芽細胞の分泌した自己コラーゲン線維、いわゆる真 皮様組織に置き換わる。本治療法の欠点は真皮様組織の再生が $2 、 3$ 週と長期に及ぶこと、移植早期には感染に弱く、特に 難治性潰瘍などでは融解し、真皮様組織が形成されないことである。これを回避するために、塩基性線維芽細胞増殖因子 （bFGF）があつ創傷治癒促進効果を利用する方法が考案されている。この方法はゼラチンの微粒子をスポンジ内に直接注 入する方法であるが、この方法は臨床現場では非常に煩雑である。そこで、スポンジ自体に bFGFの徐放効果をあたせるた めに、作製段階で各種濃度のゼラチンを組み込んだコラーゲンノゼラチンスポンジを作製し、In vitro で細胞増殖、In vivo で bFGF の徐放、組織再生について比較検討した。

ゼラチンの重量％濃度を 0、10、30、50の 4 種類とし、コラーゲンとゼラチンの混合溶液を作製した。これを従来のコラ ーゲンスポンジと同様の作製法でコラーゲンノゼラチンスポンジを作製した。これらのスポンジの平均ポアサイズを走査電 子顕微鏡を用いて計測した。また、蛍光ラベルしたゼラチンにてスポンジを作製し、スポンジ内のゼラチンの分布を観察し た。これらの結果、ゼラチン濃度が増加するにつれて、ポアサイズは縮小し、蛍光が強くなっていた。ゼラチンがスポンジ に均一に組み込まれていることあ観察された。

スポンジを基材として評価するために、In vitroで各種スポンジにおける細胞数を比較検討した。線維芽細胞を播種した well 上にスポンジを置き、1、3、5、7 日後のスポンジ内の細胞数を DNA 法にて測定した。この結果、スポンジ間に有意差 は認めなかった。

次に、 ${ }^{125} \mathrm{I}$ 放射ラベル化した bFGF を用いて、スポンジからの bFGF の徐放を In vivo で比較検討した。bFGFを含浸さ せたスポンジをマウス背部に移植し、3、7、10 日後のスポンジ内に残存する放射活性を測定した。この結果、コラーゲン単 独のスポンジよりゼラチン含有スポンジで多く徐放されていることが確認されたが、その中でも、ゼラチンを 10 むしは 30\%含むコラーゲンノゼラチンスポンジが特に、徐放効果が高かった。

さらに、スポンジ移植により形成される真皮様組織についても比較検討した。bFGF を含浸させたスポンジをウサギ耳介 に移植し、3、7、10、14 日後に真皮様組織内のへモグロビン量を測定、また、28、90 日後の真皮様組織の断面積を計測し た。コントロールはコラーゲンスポンジに生理食塩水を含浸させたあのとした。へモグロビン量では 7 日後にゼラチンを 10\%含むコラーゲンノゼラチンスポンジが有意差をむって良好な結果が得られ、28 日後の面積でもこのスポンジが有意に大 きな真皮様組織を形成した。また、90日後の面積はbFGF を投与した群ではコントロールと比べ、大きな組織を形成した。

ゼラチンを $10 \%$ 含むコラーゲン /ゼラチンスポンジは、コラーゲンスポンジと同様の使用む可能であるが、bFGF と組み 合わせることにより、現在のコラーゲンスポンジの問題点を解決できる有用な治療法となると考えられる。即ち、真皮様組 織形成の期間を短縮し、難治性潰瘍にも使用可能と考えられる。また、bFGF 以外の他の成長因子などむ徐放できる可能性 
がある。このような成長因子を徐放できる基材は他にはなく、再生医療に拈いても、中心的な基材になると考えられる。

\section{論 文 審 査 の 結 果 の 要 旨}

コラーゲンスポンジはゼラチン粒子の併用で、bFGF を徐放させる足場となりうるが、注入手技が煩雑なため、臨床応用 は困難である。そのため、コラーゲンとゼラチンの混合液から、従来のコラーゲンスポンジと同様の方法でスポンジを作製、 bFGF 併用時の有用性を検討した。ゼラチン濃度は 0、10、30、50wt％とした。

各種スポンジを走査型電子顕微鏡にて観察、平均孔径を測定すると、ゼラチン濃度の上昇とともに、縮小傾向が認められ たむのの、必要孔径を保っていた。RITC ラベルゼラチンにてスポンジを作製すると、ゼラチンはスポンジ内に均一に分布 していた。

96well plate に線維芽細胞を播種、12 時間後、スポンジを各 well に置き、培養後、スポンジ内の細胞数を DNA 法にて測 定したが、スポンジ間に有意差はなかった。

次に、スポンジに放射ラベル化した bFGF を合浸、マウス背部に移植し、残存放射活性を測定した。ゼラチン 10 、 $30 \%$ のスポンジが優れた bFGF 徐放能を有していた。

更に、bFGF を合浸させた各スポンジをウサギ耳介皮膚欠損創に移植したところ、ゼラチン $10 \%$ のポンジで最む血行の 豊富な組織再構築を認めた。

以上の研究は、ゼラチン $10 \%$ 含有コラーゲン /ゼラチンスポンジの人工真皮括よび再生医療材料としての臨床応用の可能 性を示唆しており、今後の治療法の進歩に寄与するところが多い。

したがって、本論文は博士 (医学) の学位論文として価値あるあのと認める。

な㧍、本学位授与申請者は、平成 20 年 3 月 10 日実施の論文内容とそれに関連した試問を受け、合格と認められたもので ある。 